\title{
SISTEM PENDUKUNG KEPUTUSAN UNTUK PEMILIHAN KONSENTRASI MATA KULIAH (STUDI KASUS PROGRAM STUDI SISTEM INFORMASI UNIKOM)
}

\author{
Annisa Paramitha Fadillah ${ }^{1}$, Muhammad Rajab Fachrizal ${ }^{2}$ \\ Program Studi Sistem Informasi, Universitas Komputer Indonesia \\ annisa@email.unikom.ac.id ${ }^{1}, \underline{\text { rajab@email.unikom.ac.id }}^{2}$
}

\begin{abstract}
ABSTRAK
UNIKOM adalah salah satu perguruan tinggi swasta yang terkenal di Bandung. UNIKOM memeiliki beberapa program studi yang cukup besar salah satunya program studi sistem informasi. Prodi sistem informasi menerapkan kurikulum yang mewajibkan mahasiswa pada semester 6 untuk memilih konsentrasi mata kuliah berdasarkan minatnya. Akan tetapi mahasiswa terkadang merasa kesulitan untuk memililh konsentrasi mata kuliah tersebut, sehingga mahasiswa biasanya akan meminta saran dosen wali. Pada penelitian sebelumnya dengan judul "penerapan nä̈ve bayes classifier untuk pemilihan konsentrasi mata kuliah" [1] telah dipaparkan mengenai pemodelan menggunakan metode naïve bayes itu sendiri. Pada penelitian ini akan membahas mengenai perancangan sistem pendukung keputusan yang didalamnya menggunakan metode naïve bayes. Diharapkan dengan adanya sistem pendukung keputusan ini, dapat mempermudah dalam memberikan rekomendasi pemilihan konsentrasi mata kuliah baik untuk mahasiswa maupun dosen wali.. Penggunaan nä̈ve bayes classifier, dikarenakan nä̈ve bayes classifier merupakan metode yang mudah dipahami dan cukup sederhana.
\end{abstract}

Kata kunci: Sistem pendukung keputusan, Naïve Bayes, Data mining.

\section{Pendahuluan}

1.1.Latar Belakang Masalah

Sistem Pendukung Keputusan (SPK) adalah sebuah sistem yang mampu memberikan kemampuan pemecahan masalah maupun kemampuan pengkomunikasian untuk masalah dengan kondisi semi terstruktur dan tak terstruktur.

SPK bertujuan untuk menyediakan informasi, membimbing, memberikan prediksi serta mengarahkan kepada pengguna informasi agar dapat melakukan pengambilan keputusan dengan lebih baik .

Penelitian ini merupakan penelitian lanjutan dari penelitian sebelumnya dengan judul "penerapan nä̈ve bayes classifier untuk pemilihan konsentrasi mata kuliah", pada penelitian sebelumnya telah dipaparkan mengenai bagaimana tahapan pengumpulan data, tahapan pemodelan dan rekomendasi. Pada penelitian ini hasil dari pemodelan pada penelitian sebelumnya akan menjadi acuan dalam perancangan sistem pendukung keputusan yang akan dibuat.

Tujuan dari pembangunan sistem pendukung keputusan ini, terkait dengan masalah yang ada program studi sistem informasi, yaitu mahasiswa pada prodi sistem informasi diwajibkan untuk memilih konsentrasi mata kuliah. Akan tetapi terkadang baik mahasiswa bahkan dosen wali masih kesulitan untuk menentukan pilihan konsentrasi mata kuliah yang sesuai dengan mahasiswa yang bersangkutan. Hal ini menyebabkan banyak mahasiswa yang akhirnya merasa salah memilih konsentrasi mata kuliah, sehingga factor ini juga menyebabkan mahasiswa sulit lulua tepat waktu, karena mahasiswa harus mengulang konsentrasi mata kuliah lain.

\subsection{Identifikasi Masalah}


Berdasarkan uraian latarbelakang masalah di atas maka dapat diketahui identifikasi masalah adalah sebagai berikut :

1. Dosen Wali masih kesulitan dalam memberikan rekomendasi pemilihan mata kuliah.

2. Belum adanya sistem yang dapat membantu pengambilan keputusan, untuk memberikan rekomendasi pemilihan mata kuliah pada proram studi sistem informasi UNIKOM.

3. Perlu dibangunnya sistem endukung keputusan untuk mempermudah proses analisis dan pengolahan data serta rekomendasi mengenai pemilihan konsentrasi mata kuliah mahasiswa.

\subsection{Rumusan Masalah}

1. Bagaimana merancang standar untuk pemilihan konsentrasi pemilihan mata kuliah di program studi sistem informasi untuk mahasiswa semester 6 UNIKOM.

2. Bagaimana merancang suatu rekomendasi untuk pemilihan konsentrasi mata kuliah mahasiswa di program studi sistem informasi UNIKOM.

3. Bagaimana membangun sistem pendukung keputusan untuk pemilihan konsentrasi mata kuliah di program studi sistem informasi UNIKOM.

\subsection{Batasan Masalah}

1. Pemodelan menggunakan naïve bayes, pada program studi sistem informasi dengan kurikulum 2012.

2. Hanya terdapat dua pilihan konsentrasi mata kuliah, yaitu Rekayasa Sistem Informasi dan Teknologi Informasi.

3. Parameter yang digunakan dalam perhitungan naïve bayes hanya berdasarkan nilai mata kuliah yang terkait dengan pilihan konsentrasi mata kuliah.

4. Implementasi SPK hanya dilakukan pada prodi sistem informasi UNIKOM.

2. LANDASAN TEORI

2.1. Tinjauan Pustaka

Penelitian ini pengembangan dari penelitian sebelumnya yang berjudul "Classification of Subject Concentration using Algorithm C4.5", penelitian sebelumnya menggunakan algoritma C4.5 dalam tahapan pemodelannya, dan menghasilkan rekomendasi pola berupa pohon keputusan. [2] Sedangkan dalam penelitian ini membahas mengenai pembangunan sistem pendukung keputusan yang dapat membantu memberikan rekomendasi pemilihan konsentrasi mata kuliah, dan metode yang digunakan adalah naïve bayes classifier.

Penelitian yang berkaitan dengan penelitian ini salah satunya yaitu, penelitian dengan judul Data Mining Menggunakan Algoritma Nä̈ve Bayes Untuk Klasifikasi Kelulusan Mahasiswa Universitas Dian Nuswantoro. Penelitian tersebut membahas klasifikasi kelulusan mahasiswa, dan peningkatan maupun penurunan kelulusan mahasiswa, sebagai salah satu bahan evaluasi dalam penentuan kebijakan. [3]

Penelitian berikutnya yang terkait, yaitu berjudul teknik data mining menggunakan metode bayes classifier untuk optimalisasi pencarian pada aplikasi perpustakaan (studi kasus: perpustakaan Universitas Pasundan - Bandung). Penelitian ini menggunakan Nä̈ve Bayes Classfier untuk klasifikasi dokumen (di sini dokumen berupa data buku yang ada di perpustakaan) yang akan diterapkan dalam membangun perangkat lunak pencarian pada Aplikasi Perpustakaan. Fungsinya untuk mempercepat proses pencarian data buku pada Aplikasi Perpustakaan sehingga membantu meningkatkan pelayanan pada perpustakaan. [4]

Selain mengenai pemodelan, ada beberapa penelitian yang dijadikan bahan acuan untuk melakukan penelitian ini salah satunya penelitian dengan judul, "Sistem Pendukung Keputusan Seleksi Ujian Masuk Perguruan Tinggi Menggunakan NaÏve Bayes Classifier". Pengolahan data yang dilakukan 
dalam penelitian tersebut mengenai, data peserta ujian saringan masuk Universitas, untuk mengetahui apakah calon mahasiswa direkomendasikan untuk masuk ke Universitas yang dituju. [5]

Penelitian lain yang terkait dengan sistem pendukung keputusan, yaitu berjudul "sistem pendukung keputusan untuk merekomendasikan cabang baru pada outlet resto BMC". Penelitian ini membahas mengenai pembangunan sistem pendukung keputusan untuk membantu pemilihan cabang baru dengan menggunakan metode WP (Weigthed Product). [6]

\section{Metode Penelitian}

\subsection{Metode Pengembangan}

Metode Pengembangan yang digunakan dalam penelitian ini adalah metode prototype, penggunaan metode ini berfokus pada keinginan pelanggan, dalam kasus ini pembangunan sistem pendukung keputusan disesuaikan dengan kebutuhan user yaitu dosen wali dan mahasiswa, yang disesuaikan dengan tujuan utama, untuk mempermudah dalam pemilihan konsentrasi mata kuliah, dan memberikan rekomendasi untuk pemilihan konsentrasi mata kuliah berdasarkan nilai mahasiswa.

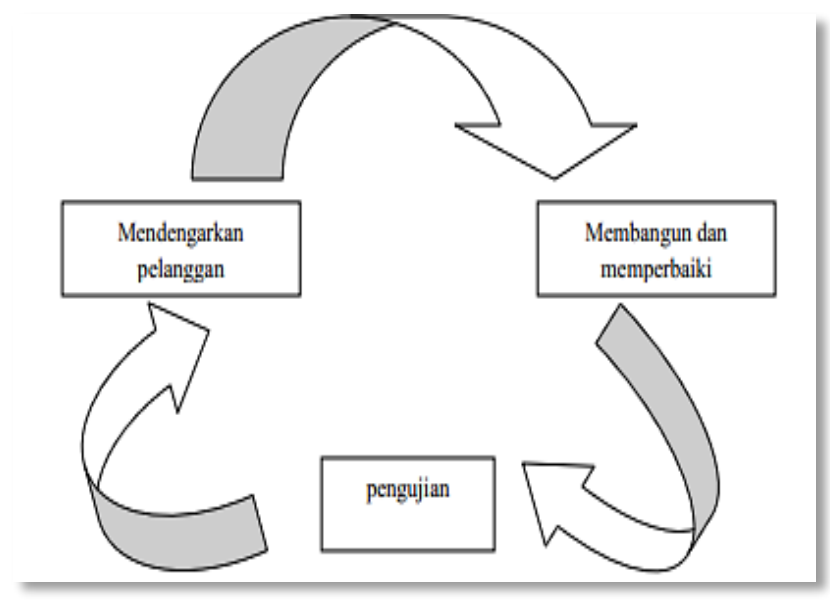

Gambar 1 Model Prototype Paradigma

(Sumber :Rekayasa Perangkat Lunak) [7]

\subsection{Tahapan Penelitian}

Tahapan penelitian yang dilakukan mengacu pada model penelitian dan pengembangan dengan model prototype. Adapun tahapannya adalah sebagai berikut:

Tahap I : Studi Pendahuluan, tahapan ini meliputi:

1. Tahapan ini diawali dengan studi literatur dan pustaka.

2. Kemudian studi/pengumpulan data di lapangan tentang sistem yang akan dibangun.

3. Melakukan identifikasi permasalahan yang di temukan di lapangan.

Tahap II : Proses Data Mining

1. Proses persiapan data, melakukan identifikasi data apa saja yang terkait untuk melakukan tahap pemodelan.

2. Pemodelan, merupakan proses perhitungan data yang telah disiapkan, tahapan pemodelan ini dilakukan dengan menggunakan nä̈ve bayes.

3. Evaluasi, evaluasi pada tahap keuda merupak proses evaluasi dari hasil pemodelan naïve bayes. Jika tahap pemodelan sudah sesuai maka tahap selanjutnya dapat dilaksanakan.

Tahap III : Pembangunan SPK

1. Perancangan Sistem, melakukan penggambaran sistem yang akan dibangun. 
2. Pembangunan sistem, proses pembuatan sistem berdasarkan hasil rancangan sistem pada tahap sebelumnya.

3. Perbaikan Sistem, Prototype yang dibuat disesuaikan dengan kebutuhan sistem, dan hasil dari perhitungan nä̈ve bayes yang telah didefiniskan sebelumnya.

4. Uji Coba Sistem, sistem di uji coba oleh pengguna. Kemudian dilakukan evaluasi kekurangankekurangan dari kebutuhan pelanggan.

\section{Pembahasan dan Hasil Penelitian}

Penelitian ini mengacu pada hasil pemodelan pada penelitian sebelumnya dengan judul penerapan naüve bayes classifier untuk pemilihan konsentrasi mata kuliah, sehingga pada peneltian ini hanya akan membahas mengenai pembangunan SPK.

\subsection{Pemodelan}

Pada tahapan pemodelan yang telah dilakukan pada penelitian sebelumnya, telah diketahui hasil perhitungan yang akan menjadi acuan untuk pembuatan SPK. Penggunaan data awal sebagai data latih (data awal), merupakan data yang sama. Perhitungan yang pertama kali dilakukan adalah menghitung $\mathrm{P}(\mathrm{X})$, probabilitas untuk konsentrasi mata kuliah Teknologi Informasi dan Rekayasa Sistem Informasi. Hasil perhitungan dapat dilihat pada tabel berikut :
1. $\mathrm{P}(\mathrm{RSI})$
$=22 / 37$
$=0,595$
2. $\mathrm{P}(\mathrm{TI})$
$=15 / 37$
$=0,405$

Kemudian tahap berikutnya adalah melakukan perhitungan probabilitas $\mathrm{X}$ berdasar kondisi pada hipotesis $\mathrm{H}$, untuk setiap atribut yang ada pada matakuliah. Berikut perhitungan menggunakan nä̈ve bayes:

Tabel 6 Contoh Hasil perhitungan Naïve Bayes

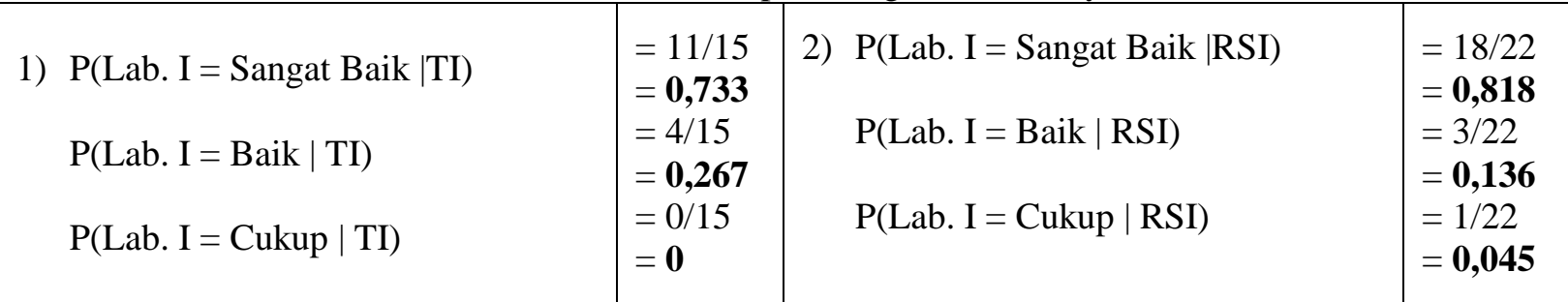

Kemudian dari hasil perhitungan diatas, menjadi acuan sementara untuk membangun SPK.

\subsection{Perancangan Sistem}

Pada tahap ini, hasil perhitungan menggunakan nä̈ve bayes, akan dijadikan acuan sementara untuk melakukan perancangan SPK. Berikut adalah usecase dari sistem yang akan dirancang : 


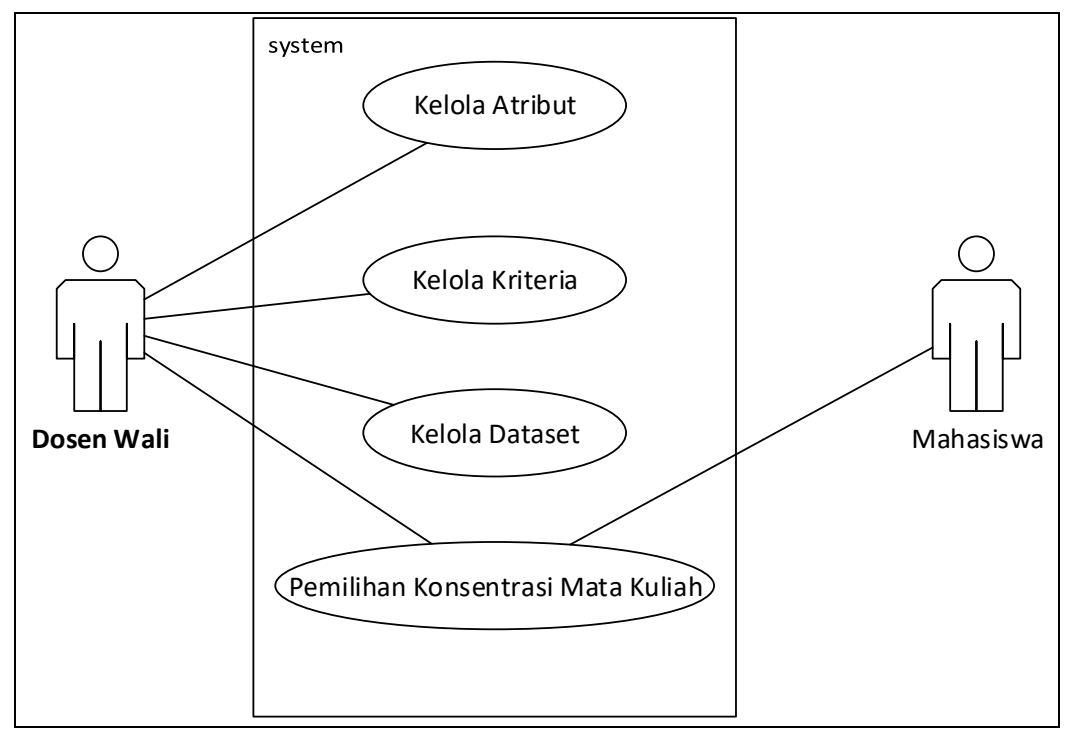

Gambar 2 Usecase Diagram

Tabel 1 Deskripsi Aktor

\begin{tabular}{|l|l|}
\hline Deskripsi Aktor & $\begin{array}{l}\text { Dosen wali sebagai aktor yang diberikan akses } \\
\text { keseluruhan dalam sistem. }\end{array}$ \\
\hline Dosen Wali & $\begin{array}{l}\text { Mahasiswa dapat melakukan proses analisis pemilihan } \\
\text { konsentrasi mata kuliah, sesuai dengan data yang sudah } \\
\text { ada sebelumnya. }\end{array}$ \\
\hline
\end{tabular}

Tabel 2 Deskripsi Usecase

\begin{tabular}{|c|c|}
\hline \multicolumn{2}{|l|}{ Deskripsi Usecase } \\
\hline Kelola Atribut & $\begin{array}{l}\text { Pengelolaan data atribut, dalam kasus ini adalah data mata } \\
\text { kuliah yang terkait dengan pemilihan konsentrasi mata } \\
\text { kuliah. }\end{array}$ \\
\hline Kelola Kriteria & $\begin{array}{l}\text { Pengelolaan data kriteria, dalam kasus ini adalah data nilai } \\
\text { atribut untuk setiap mata kuliah yang terkait dengan } \\
\text { pemilihan konsentrasi mata kuliah, yang telah dikonversi } \\
\text { kedalam bentuk predikat (contohnya : sangat baik, baik, } \\
\text { cukup,dst). }\end{array}$ \\
\hline Kelola Data Set & $\begin{array}{l}\text { Pengelolaan data set, adalah pengelolaan data untuk } \\
\text { perhitungan naïve bayes (data latih / data training) }\end{array}$ \\
\hline $\begin{array}{ll}\text { Pemilihan } & \text { Konsentrasi } \\
\text { Matakuliah } & \end{array}$ & $\begin{array}{l}\text { Proses perhitungan dengan naïve bayes, untuk memberikan } \\
\text { rekomendasi pilihan konsentrasi mata kuliah, Teknologi } \\
\text { Informasi maupun Rekayasa Sistem Informasi }\end{array}$ \\
\hline
\end{tabular}




\subsection{Implementasi antar muka}

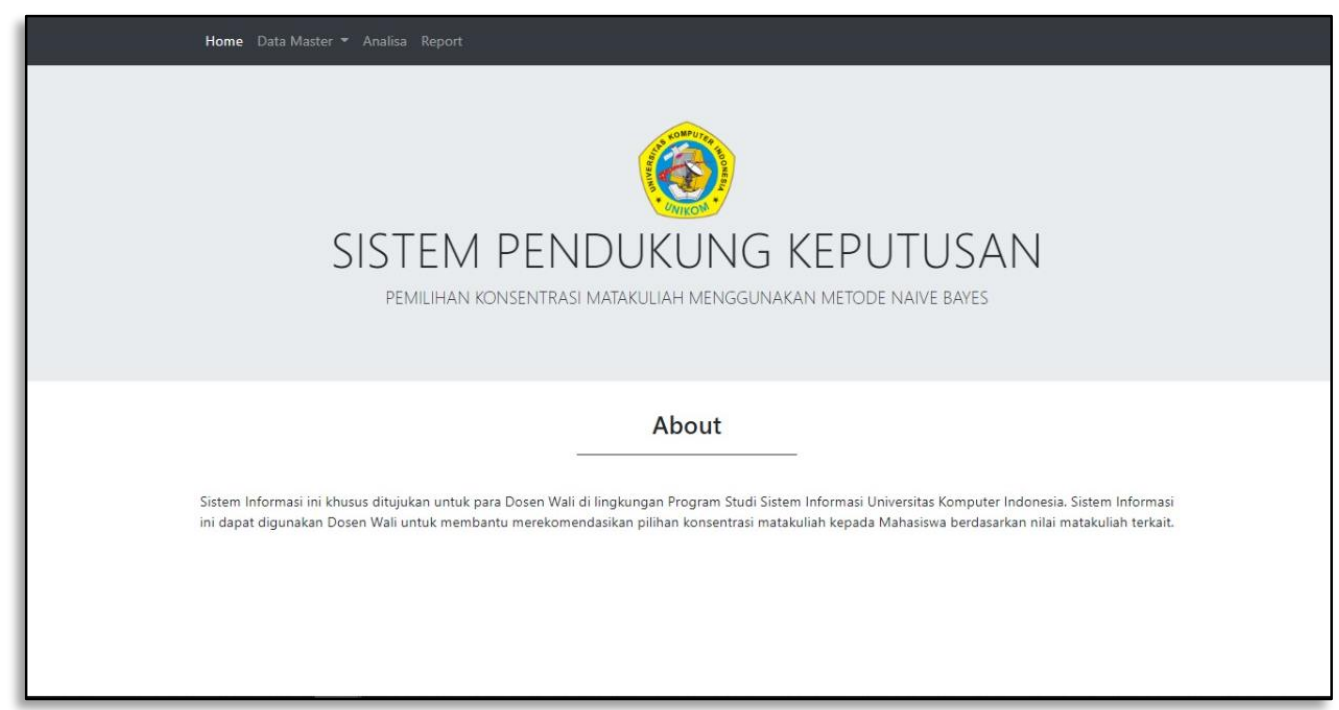

Gambar 3 Tampilan awal

Pada Gambar 3 merupakan tampilan awal sistem ketika pertama kali di akses, sistem pendukung keputusan ini memiliki dua akses, yaitu mahasiswa dan dosen wali.

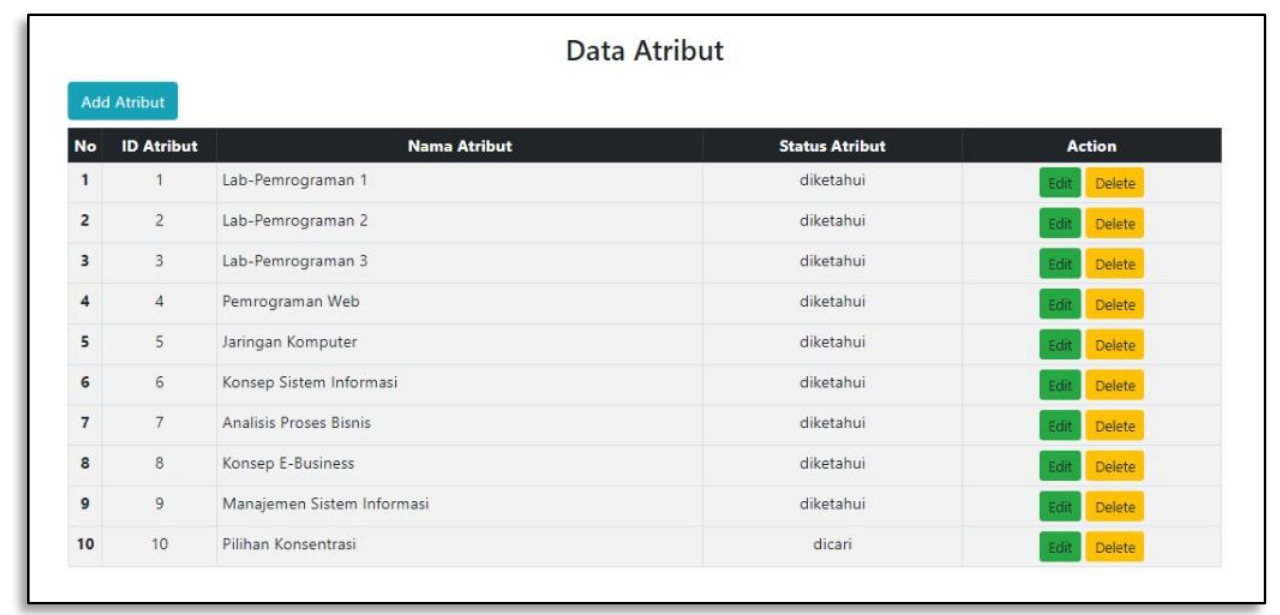

Gambar 4 Halaman Kelola Atribut

Pada Gambar 4 menampilkan halaman yang berfungsi pengelolaan data atribut, dalam kasus ini adalah data mata kuliah yang terkait dengan pemilihan konsentrasi mata kuliah. Pada halaman ini atribut yang terkait dengan pilihan konsentrasi mata kuliah dapat ditambahkan maupun dikurangi, disesuaikan dengan hasil pemodelan naïve bayes. 


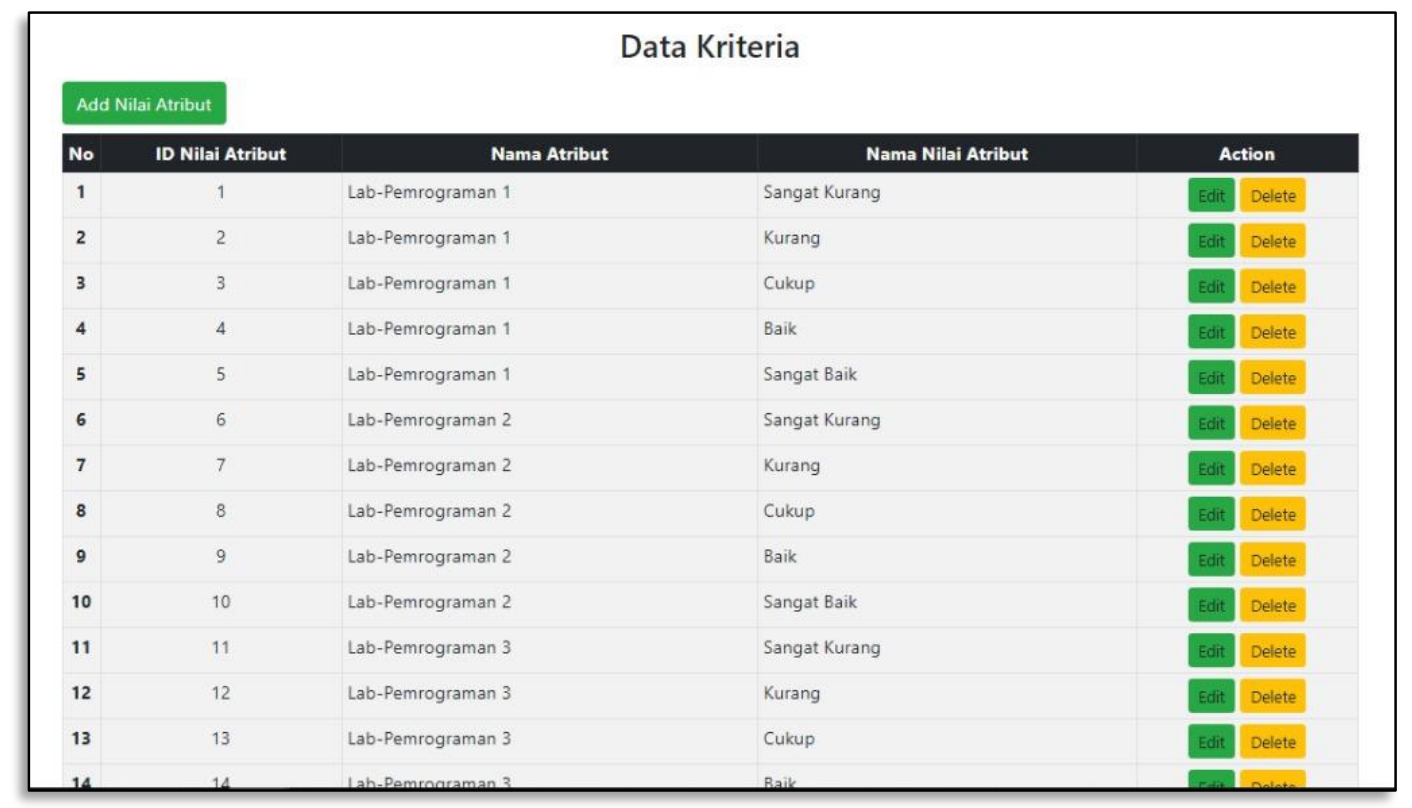

\section{Gambar 5 Halaman kelola data kriteria}

Pada Gambar 5 menampilkan halaman yang berfungsi pengelolaan data kriteria, adalah data nilai atribut untuk setiap mata kuliah yang terkait dengan pemilihan konsentrasi mata kuliah, yang telah dikonversi kedalam bentuk predikat (contohnya : sangat baik, baik, cukup,dst).

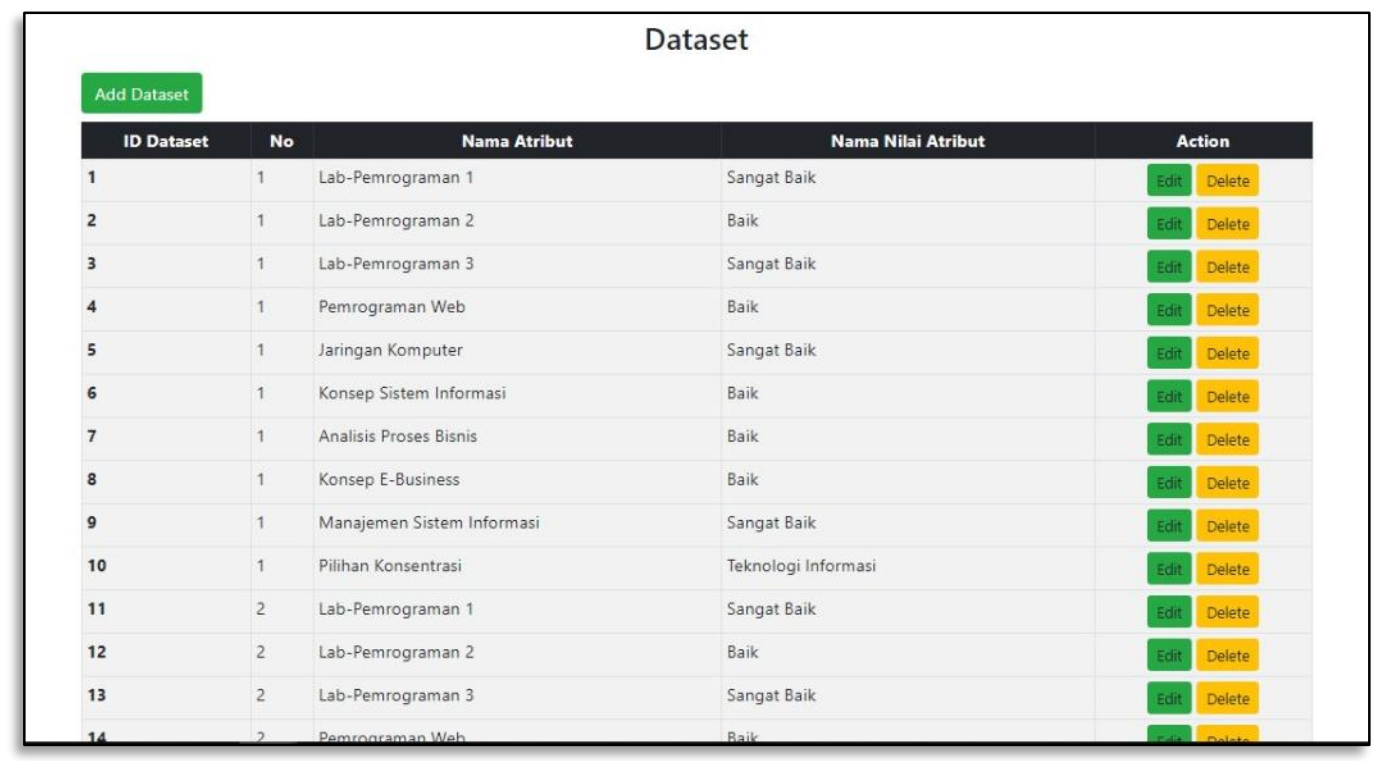

Gambar 6 Halaman Kelola Dataset

Pada Gambar 6, menampilkan halaman pengelolaan dataset berfungsi untuk mengatur data training (data set) yang akan dijadikan acuan dalam perhitungan data mining menggunakan nä̈ve bayes. 


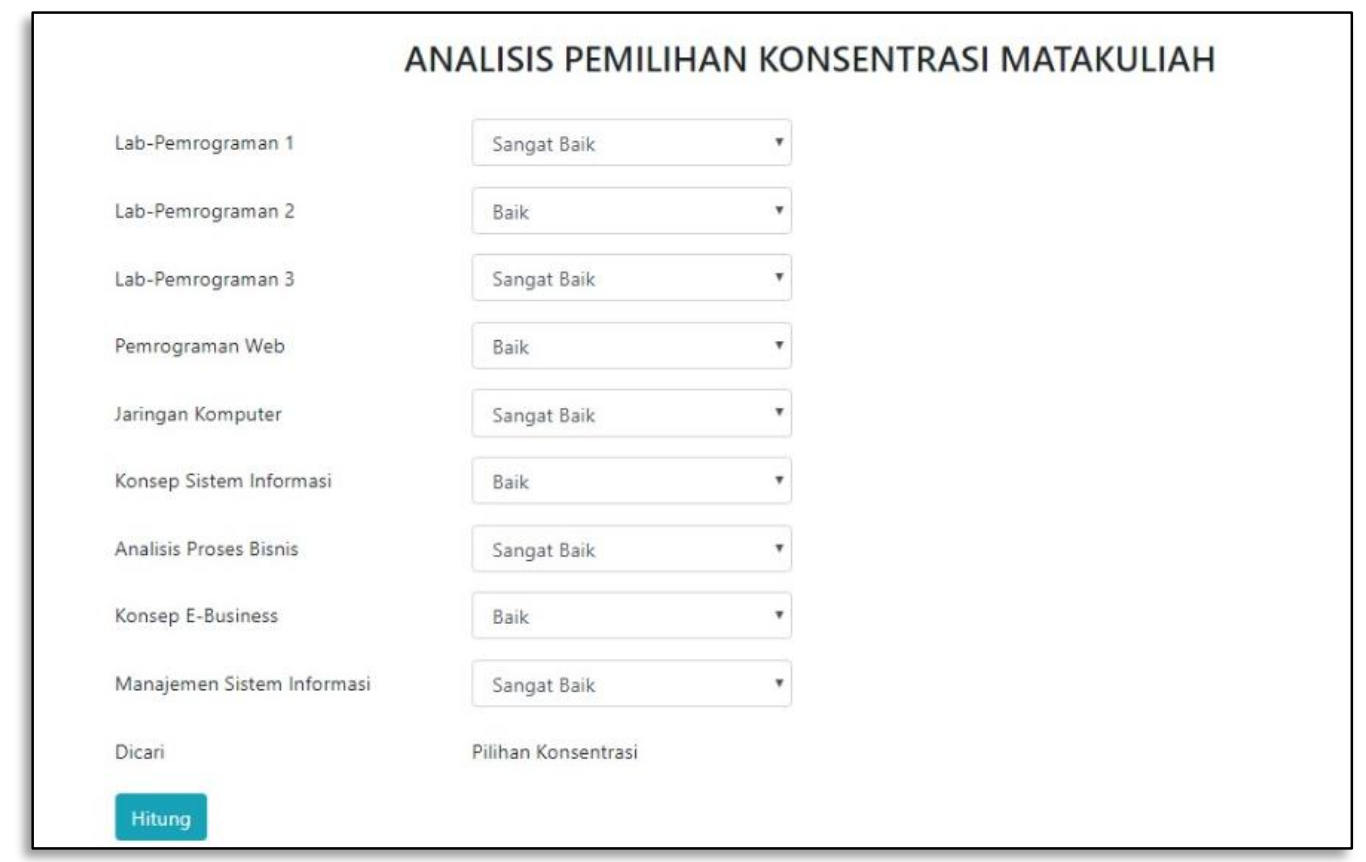

Gambar 7 Halaman analisis konsentrasi mata kuliah

Pada Gambar 7, menampilkan halaman yang berfungsi untuk melakukan analisis konsentrsai mata kuliah, halaman ini dapat di akses oleh dosen wali maupun mahasiswa. Pada halaman ini user harus menginputkan data nilai berdasarkan predikat yang didapat, sehingga akan menghasilkan sebuah rekomendasi konsentrasi matakuliah manakah yang cocok berdasarkan parameter ini yang telah diinputkan tersebut.

\begin{tabular}{|c|c|c|c|c|c|}
\hline \multicolumn{6}{|c|}{ ANALISIS PEMILIHAN KONSENTRASI MATAKULIAH } \\
\hline Atribut Diketahui & Nilai Atribut & Atribut Dicari Pilihan Konsentrasi & Jumlah Dataset & Jumlah Dataset Dicari & Total Nilai \\
\hline \multirow[t]{2}{*}{ Lab-Pemrograman 1} & \multirow[t]{2}{*}{ Sangat Baik } & Rekayasa Sistem Informasi & 16 & 18 & 0.88888888888889 \\
\hline & & Teknologi Informasi & 10 & 13 & 0.76923076923077 \\
\hline \multirow[t]{2}{*}{ Lab-Pemrograman 2} & \multirow[t]{2}{*}{ Baik } & Rekayasa Sistem Informasi & 13 & 18 & 0.722222222222222 \\
\hline & & Teknologi Informasi & 4 & 13 & 0.30769230769231 \\
\hline \multirow[t]{2}{*}{ Lab-Pemrograman 3} & \multirow[t]{2}{*}{ Sangat Baik } & Rekayasa Sistem Informasi & 8 & 18 & 0.44444444444444 \\
\hline & & Teknologi Informasi & 10 & 13 & 0.76923076923077 \\
\hline \multirow[t]{2}{*}{ Pemrograman Web } & \multirow[t]{2}{*}{ Baik } & Rekayasa Sistem Informasi & 11 & 18 & 0.611111111111111 \\
\hline & & Teknologi Informasi & 5 & 13 & 0.38461538461538 \\
\hline \multirow[t]{2}{*}{ Jaringan Komputer } & \multirow[t]{2}{*}{ Sangat Baik } & Rekayasa Sistem Informasi & 16 & 18 & 0.88888888888889 \\
\hline & & Teknologi Informasi & 10 & 13 & 0.76923076923077 \\
\hline \multirow[t]{2}{*}{ Konsep Sistem Informasi } & \multirow[t]{2}{*}{ Baik } & Rekayasa Sistem Informasi & 7 & 18 & 0.38888888888889 \\
\hline & & Teknologi Informasi & 6 & 13 & 0.46153846153846 \\
\hline \multirow[t]{2}{*}{ Analisis Proses Bisnis } & \multirow[t]{2}{*}{ Sangat Baik } & Rekayasa Sistem Informasi & 7 & 18 & 0.38888888888889 \\
\hline & & Teknologi Informasi & 3 & 13 & 0.23076923076923 \\
\hline \multirow[t]{2}{*}{ Konsep E-Business } & \multirow[t]{2}{*}{ Baik } & Rekayasa Sistem Informasi & 4 & 18 & 0.222222222222222 \\
\hline & & Teknologi Informasi & 4 & 13 & 0.30769230769231 \\
\hline \multirow[t]{2}{*}{ Manajemen Sistem Informasi } & \multirow[t]{2}{*}{ Sangat Baik } & Rekayasa Sistem Informasi & 15 & 18 & 0.83333333333333 \\
\hline & & Teknologi Informasi & 10 & 13 & 0.76923076923077 \\
\hline
\end{tabular}

Gambar 8 Hasil rekomendasi (awal) 


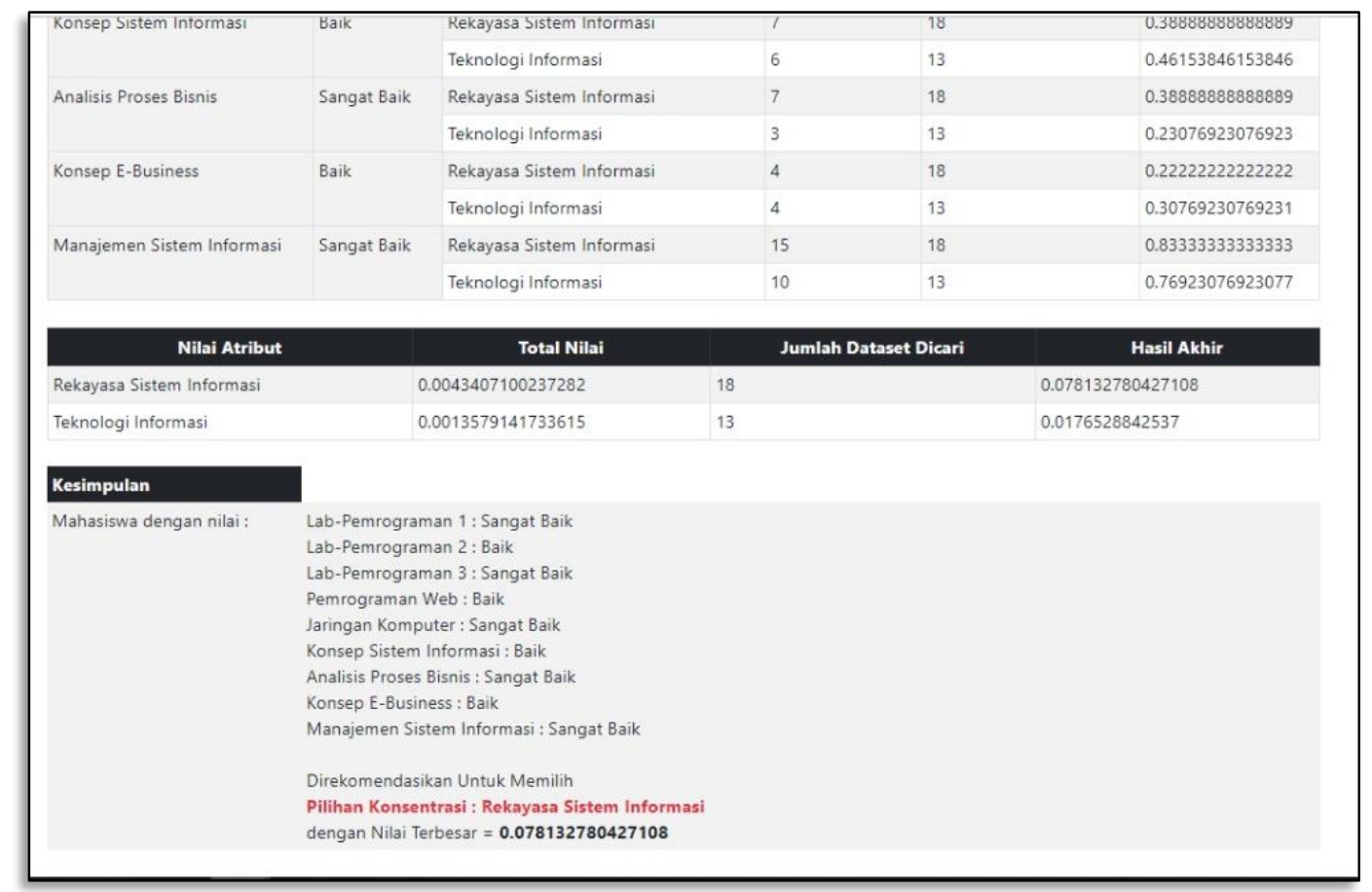

Gambar 9 Hasil Rekomendasi (lanjutan)

Pada Gambar 8 dan Gambar 9 dapat dilihat merupakan hasil rekomendasi dari analisis yang telah dilakukan pada halaman analisis (Gambar 7), pada gambar 8 dan gambar 9 juga dapat terlihat hasil dari perhitungan naïve bayes yang diterapkan pada SPK ini. Hasil ini hanya merupakan rekomendasi pilihan konsentrasi mata kuliah, pemilihan konsentrasi mata kuliah untuk mahasiswa tidak diharuskan sesuai dengan hasil rekomendasi yang telah diberikan oleh sistem.

\section{KESIMPULAN DAN SARAN}

\subsection{Kesimpulan}

Berdasarkan hasil penelitian yang dilakukan, dapat diambil kesimpulan sebagai berikut :

1. Pemodelan dengan menggunakan naïve bayes, mempermudah dalam proses pembuatan standar untuk pemilihan konsentrasi mata kuliah, berdasarkan data - data yang telah ada sebelumnya. Naïve bayes menghitung peluang dari data - data yang sudah ada sebelumnya kemudian, data yang akan di test akan memperoleh model perkiraan berdasarkan data yang ada.

2. Dengan adanya sistem pendukung keputusan ini, dosen wali akan dapat memberikan rekomendasi dalam pilihan konsentrasi mata kuliah untuk mahasiswa wali, sehingga mahasiswa mendapatkan gambaran mengenai konsentrasi yang akan diambil.

\subsection{Saran}

Berdasarkan kesimpulan yang dipaparkan, hal yang diharapkan adalah sebagai berikut:

1. Dapat menerapkan kurikulum yang berjalan saat ini pada prodi sistem informasi UNIKOM.

2. Sistem pendukung keputusan ini diharapkan dapat membantu program studi lain yang memiliki kasus yang serupa dengan yang ada pada program stusi sistem informasi UNIKOM.

3. Pada pengembangan sistem berikutnya parameter yang digunakan dapat ditambahkan, tidak hanya berdasarkan penilaian mata kuliah.

4. Menggunakan pemodelan lain selain menggunakan nä̈ve bayes, agar hasil rekomendasi dapat lebih akurat. 


\section{UCAPAN TERIMA KASIH}

Ucapan terimakasih ditujukan kepada Lembaga Penelitian dan Pengabdian Masyarakat Universitas Komputer Indonesia yang telah mendanai penelitian ini.

\section{DAFTAR PUSTAKA}

[1] A. P. Fadillah and B. Hardiyana, "Penerapan naïve bayes classifier untuk pemilihan konsentrasi mata kuliah," Jati, 2018.

[2] A. P. Fadillah and B. Hardiyana, "Classification of Subject Concentration using Algorithm C4.5," in INCITEST-IOP conference series : Science \& Engineering, Bandung, 2018.

[3] Y. S. Nugroho, "DATA MINING MENGGUNAKAN ALGORITMA NAÏVE BAYES UNTUK KLASIFIKASI KELULUSAN MAHASISWA UNIVERSITAS DIAN NUSWANTORO,” 2014.

[4] S. L. B. Ginting and R. P. Trinanda, "TEKNIK DATA MINING MENGGUNAKAN METODE BAYES CLASSIFIER UNTUK OPTIMALISASI PENCARIAN PADA APLIKASI PERPUSTAKAAN (STUDI KASUS : PERPUSTAKAAN UNIVERSITAS PASUNDAN BANDUNG)," JATI : Jurnal Teknologi dan Informasi UNIKOM, vol. Volume 1 No 6, 2014.

[5] A. Suryadi and D. Nurdiana, "SISTEM PENDUKUNG KEPUTUSAN SELEKSI UJIAN MASUK PERGURUAN TINGGI MENGGUNAKAN NBC (NAÏVE BAYES CLASSIFIER)," KINETIK, Vols. Vol 1, No. 3, no. ISSN : 2503-2259; E-ISSN : 2503-2267, pp. 173-182, 2016.

[6] Darussalam and A. P. Fadillah, "SISTEM PENDUKUNG KEPUTUSAN UNTUK MEREKOMENDASIKAN CABANG BARU PADA OUTLET RESTO BMC," in Prosiding Seminar Teknik Informatika Unpad, Bandung, 2018.

[7] R. A. S. and M. S. , Rekayasa Perangkat Lunak Terstruktur dan Objek, Bandung: Penerbit Informatika, 2013.

[8] Kusrini, Algoritma Data Mining, Yogyakarta: Penerbit Andi, 2009.

[9] E. d. Turban, Decicion Support Systems and Intelligent Systems, Andi Offset, 2005.

[10] I. C. Gumilang, D. S. M. and A. R. S. , "PREDIKSI PERSEDIAAN OBAT DENGAN METODE NAÏVE BAYES (STUDI KASUS : APOTEK SAPUTRA)," PROGRAM STUDI TEKNIK INFORMATIKA, FAKULTAS KOMUNIKASI DAN INFORMATIKA UNIVERSITAS MUHAMMADIYAH SURAKARTA, Surakarta, 2014.

[11] E. Prasetyo, Data Mining konsep dan Aplikasi menggunakan MATLAB, Yogyakarta: Penerbit Andi, 2012.

[12] Suyanto, Buku Data Mining untuk Klasifikasi dan Klasterisasi Data, Bandung: Penerbit Informatika, 2017.

[13] A. P. Fadillah, "Penerapan Metode CRISP-DM untuk Prediksi Kelulusan Studi Mahasiswa Menempuh Mata Kuliah (Studi Kasus Universitas XYZ)," JUTISI, vol. VOL. 1, pp. 260-270, 3 Desember 2015. 